\title{
Evaluating factors affecting restoration of an endangered marine broadcast-spawning invertebrate using an individual-based model of white abalone
}

\author{
Yan $\mathrm{Li}^{1,3, *}$, Laura Rogers-Bennett ${ }^{1,2}$ \\ ${ }^{1}$ Department of Veterinary Medicine, Karen C. Drayer Wildlife Health Center, University of California, Davis, CA 95616, USA \\ ${ }^{2}$ California Department of Fish and Wildlife and Bodega Marine Laboratory, University of California, Davis, PO Box 247, \\ Bodega Bay, CA 94923, USA
}

${ }^{3}$ Present address: Pennsylvania Cooperative Fish and Wildlife Research Unit, Pennsylvania State University, University Park, PA 16802, USA

\begin{abstract}
Restoration and modeling of endangered species is challenging when the available data are sparse and the environmental conditions are stochastic. Using white abalone Haliotis sorenseni, a critically endangered marine broadcast spawner with spatially patchy remnant populations in southern California (USA), as an example, we developed an individual-based model that describes density-, temperature-, and habitat-dependent biological processes. Using the model, we evaluated hypothetical stocking strategies including spatial distribution and size of stocked abalone and initial density of resident abalone. Our results show that stocking strategies for the modeled white abalone populations benefited most when stocking locations had resident abalone and when stocked abalone were large in size. We also examined the potential influence of the spatial structure of the habitat (i.e. percentage of suitable habitat and spatial distribution of habitat cells), ocean warming, and poaching on restoration outcomes. We found that the percentage of suitable habitat greatly affected population dynamics, with more suitable habitat resulting in a slower decline in population growth and recruitment, as well as a higher and more stable proportion of intermediate-sized abalone. The spatial distribution (random or clustered) of habitat cells and of stocked abalone had less of an impact on model outcomes. Elevated temperature and poaching both had strong negative impacts on abalone population growth in the model. Given the spatial structure of the habitat and population, ocean warming and poaching are considered critical factors in the development of restoration strategies for endangered broadcast spawners.
\end{abstract}

KEY WORDS: Individual-based model · Habitat spatial structure Population spatial structure · Ocean warming $\cdot$ Poaching $\cdot$ Restoration $\cdot$ Haliotis sorenseni

\section{INTRODUCTION}

Broadcast spawners have external fertilization, releasing gametes into the surrounding water (Levitan \& Sewell 1998, Baker \& Tyler 2001). Dense aggregations of adults facilitate successful fertilization when high concentrations of eggs and sperm are released. Reduced population density and spatial separation between nearest-neighbor adults can have long-

${ }^{*}$ Corresponding author: yxl73@psu.edu lasting negative impacts on fertilization success, recruitment, and population dynamics. This reproductive Allee effect (i.e. density-dependent fertilization success) has been well documented for broadcast spawners including the sea urchin Diadema antillarum (Levitan 1991) and abalones Haliotis spp. (Babcock \& Keesing 1999, Button 2008, Coates \& Hovel 2014), which show nonlinear declines in fertilization success with reduced population density.

() The authors 2017. Open Access under Creative Commons by Attribution Licence. Use, distribution and reproduction are unrestricted. Authors and original publication must be credited. 
Therefore, reducing densities through exploitation and poaching can have dramatic negative impacts on the population dynamics of broadcast spawners.

Abalones are marine broadcast spawners with a long life span (up to 30-40 $\mathrm{yr}_{\text {; }}$ Cox 1960, Andrews et al. 2013), slow movement, and highly variable recruitment (Hobday \& Tegner 2000). The complex life history of abalones makes their population dynamics prone to environmental stochasticity and also makes their populations vulnerable to intensive exploitation (Karpov et al. 2000, Rogers-Bennett et al. 2002). For example, laboratory studies have shown that temperature greatly affects abalone growth and reproduction (Leighton 1974, Rogers-Bennett et al. 2010). Abalones once supported a valuable commercial fishery in California (USA); however, the fishery suffered a serial depletion and finally collapsed in 1997 (Hobday \& Tegner 2000). In 2001, white abalone $H$. sorenseni became the first marine invertebrate listed under the US Endangered Species Act, followed by the black abalone $H$. cracherodii in 2009 . Today, white abalone populations are on the brink of extinction, with low population density being the major threat (Stierhoff et al. 2012, Catton et al. 2016). Without effective restoration actions, white abalone are projected to reach the quasi-extinction threshold of 1000 individuals in the wild in the next 15 yr (Catton et al. 2016).

Restoration of endangered marine broadcast spawners is challenging due to (1) the low density of remnant populations that may limit the success of reproduction through the Allee effect, (2) limited data (e.g. survival information) that may impede the success of restoration efforts, and (3) varying environmental conditions (e.g. warming ocean temperature) that may limit the survival of stocked juveniles in the wild. The high fecundity of broadcast spawners makes their captive breeding and stocking feasible (Rogers-Bennett et al. 2016a), although success of captive breeding is still limited by the scarcity of brood stock and low spawning success. Restoration strategy evaluations can take advantage of simulation modeling that can fully use available data and also incorporate uncertainty.

Individual-based models have been widely used in the conservation and management of endangered species (and species of concern) to evaluate possible restoration strategies or simulate extinction risk. The models track the life history processes (e.g. growth, survival, and reproduction) of each individual in a population; these life history processes are tailored to individual biological characteristics, environmental variability, and individual strategies adapting to the changing environment. For example, individualbased models have been used to evaluate the effects of temperature and fishing on red abalone $H$. rufescens (Hobday \& Tegner 2002) and spiny lobsters Panulirus penicillatus (Chang et al. 2010). Coates \& Hovel (2014) developed an individual-based model to simulate fertilization success for pink abalone $H$. corrugata.

In this study, using the white abalone off the southern California coast as an example, we aimed to (1) develop an individual-based model for endangered marine broadcast spawners that incorporates spatial structure of the habitat as well as environmental stochasticity; (2) evaluate hypothetical stocking strategies including the spatial distribution and size of stocked abalone and initial density of resident abalone; (3) investigate the influences of habitat spatial structure (i.e. the percentage of suitable habitat and the spatial distribution of habitat cells, i.e. random or clustered), (4) investigate the impacts of ocean warming, (5) assess the impacts of poaching (illegal harvesting) on the efficacy of stocking strategies; and (6) make recommendations based on the model results for implementing a restoration plan for white abalone.

\section{METHODS}

\section{Model spatial structure}

Our model simulated a hypothetical spatial area of $10000 \mathrm{~m}^{2}(100 \times 100 \mathrm{~m} ; 1 \mathrm{ha})$ with suitable and less suitable habitats structured within this area (Fig. 1). The region included 100 habitat cells, and each habitat cell was $100 \mathrm{~m}^{2}(10 \times 10 \mathrm{~m})$. In the model, we used 2 types of habitat cells to represent suitable and less suitable habitat. We qualitatively related habitat suitability to abalone population dynamics. In the model, carrying capacity (i.e. maximum density of a habitat cell) and fecundity were affected by habitat suitability.

Temperature was defined as sea surface temperature $\left({ }^{\circ} \mathrm{C}\right)$ and varied monthly in the model (Fig. 2). We repeatedly appended a 1 yr average temperature dataset from San Diego, California, to simulate a $100 \mathrm{yr}$ time series. For each month, we generated a temperature based on a normal distribution with a mean of the observed average monthly temperature (January: $15^{\circ} \mathrm{C}$, February: $15.6^{\circ} \mathrm{C}$, March: $16.7^{\circ} \mathrm{C}$, April: $17.5^{\circ} \mathrm{C}$, May: $19.2^{\circ} \mathrm{C}$, June: $20.8^{\circ} \mathrm{C}$, July: $21.7^{\circ} \mathrm{C}$, August: $21.9^{\circ} \mathrm{C}$, September: $21.7^{\circ} \mathrm{C}$, October: $20.3^{\circ} \mathrm{C}$, November: $18.3^{\circ} \mathrm{C}$, December: $15.6^{\circ} \mathrm{C}$ ) and a coeffi- 

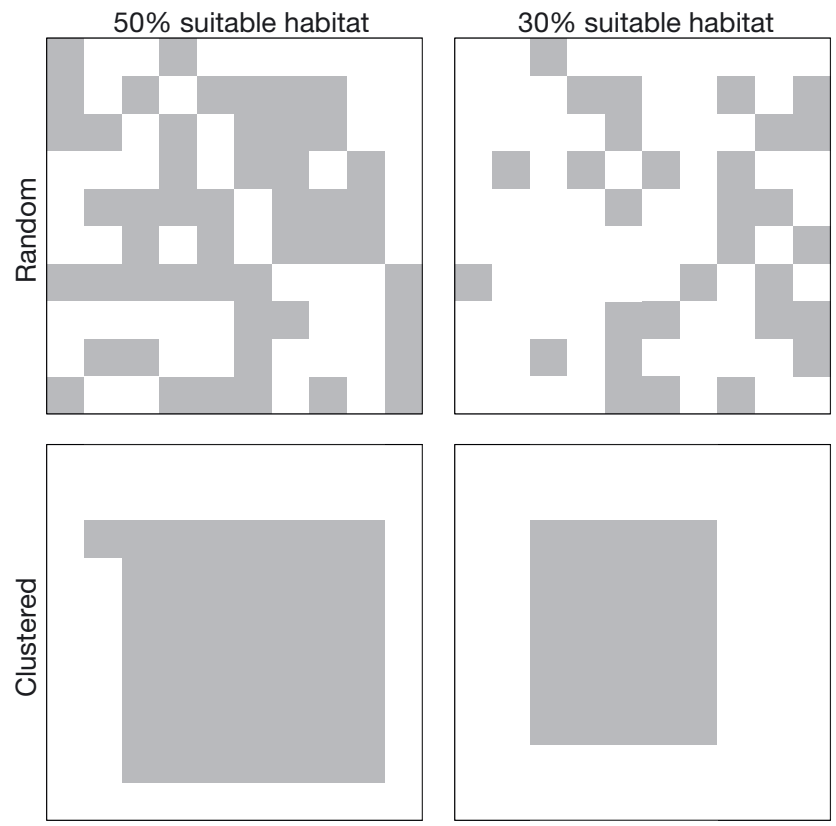

Fig. 1. Spatial framework of the hypothetical 1 ha study area, which was divided into 100 habitat cells. Each cell was considered to contain suitable or less suitable habitat, and habitats were either randomly distributed or clustered

cient of variation (CV) ranging from 5 to $10 \%$. This within-month variation seemed reasonable according to studies off the California coast (approximately 5 to $25 \% \mathrm{CV}$ for all depths up to $60 \mathrm{~m}$ based on digitized figures from Winant \& Bratkovich [1981] and Nezlin et al. [2004]). The CV was randomly selected from values between 5 and $10 \%$ for each month. Temperature did not vary among habitat cells. Water temperature data were available from the National Oceanic and Atmospheric Administration National Oceanographic Data Center (https://www.nodc.noaa.gov). For future modeling work, the temperature time series can be adjusted in the model as desired for a specific location with a temperature time series.

\section{Model parameters and assumptions}

Growth

Model parameters are summarized in Table 1. Settlement size of white abalone at $1 \mathrm{wk}$ of age was set at $0.3 \mathrm{~mm}$ (Table 1 ; L. Rogers-Bennett unpubl. data). First month growth after settlement was a random size between settlement size $(0.3 \mathrm{~mm})$ and the maximum observed size at $36 \mathrm{~d}$ of age in the laboratory (1.2 mm; Leighton 1972). White abalone were observed to reach sexual maturity at a length of 88 to $134 \mathrm{~mm}$ in a wild population (Tutschulte 1976). We used a Bernoulli distribution to determine sexual maturity for each individual within this size range. A value of 0 or 1 was generated with a success probability of 0.85 for each individual between 88 and $134 \mathrm{~mm}$; individuals receiving a value of 1 were assumed to be sexually mature, and individuals receiving a value of 0 were not mature yet. Abalone $>134 \mathrm{~mm}$ were assumed to be $100 \%$ sexually mature, and abalone $<88 \mathrm{~mm}$ were assumed to be immature. The maximum size of white abalone has been reported to be 200 to $250 \mathrm{~mm}$ (Cox 1960, Leighton 1972). A maximum size of $250 \mathrm{~mm}$ was used here.

The von Bertalanffy growth model (Quinn \& Deriso 1999) was used to describe individual growth in a monthly time step (Fig. 3a):

$$
\Delta L=\left(L_{\infty}-L\right)[1-\exp (-K \Delta t)]
$$

where $\Delta L$ is the length increment $(\mathrm{mm})$ during the month, $\Delta t=$ time period of $1 \mathrm{mo}$, and $L$ is the length at the beginning of the month. The monthly growth coefficient, $K$, was selected randomly for each individual each month from a normal distribution with mean of 0.01 and standard deviation of 0.003 . The asymptotic length $L_{\infty}$ was set to be 273.86 . These parameter values were estimated using data from Tutschulte (1976), in which a sample of 20 white

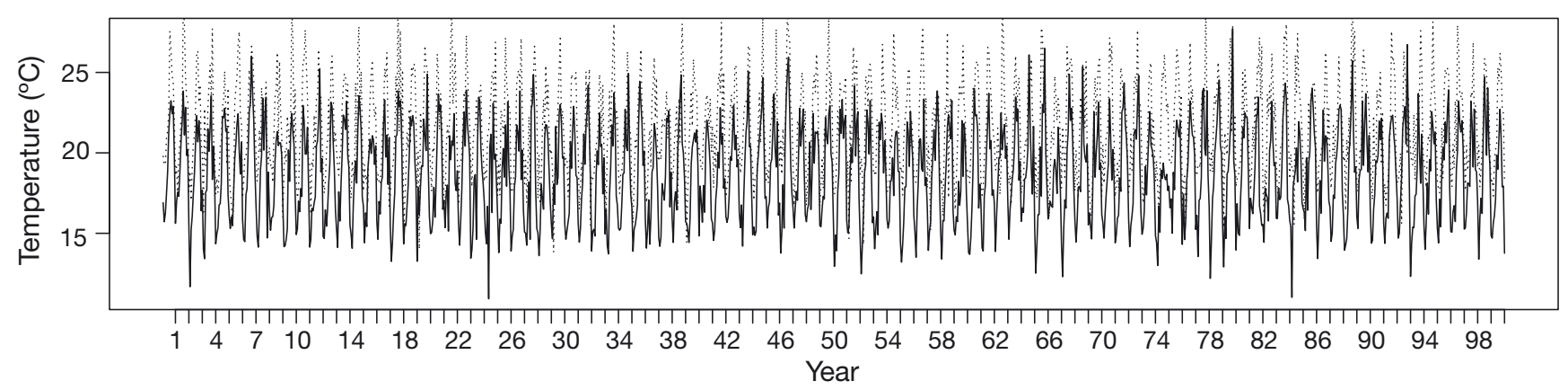

Fig. 2. Simulated time series of the monthly temperature $\left({ }^{\circ} \mathrm{C}\right)$ pattern used in the model. The dashed line was generated using an observed average pattern. The dotted line was generated using a pattern elevating the observed average pattern by $3^{\circ} \mathrm{C}$, and was used to simulate warming ocean temperature 
Table 1. Parameters and values used in the population model of white abalone Haliotis sorenseni. Details are provided in the 'Methods', and Fig. 3 shows graphical representations. $K$ : monthly growth coefficient; $L_{\infty}$ : asymptotic length: $T$ : temperature; $d$ : separation distance. Blank cells: no historical records for those parameters; assumptions based on expert opinions

\begin{tabular}{|c|c|c|}
\hline Parameter & Value & Reference \\
\hline \multicolumn{3}{|l|}{ Habitat } \\
\hline Model area & $10000 \mathrm{~m}^{2}(100 \times 100 \mathrm{~m})$ & \\
\hline Cell size & $100 \mathrm{~m}^{2}(10 \times 10 \mathrm{~m})$ & \\
\hline Maximum density & 0.23 abalone $\mathrm{m}^{-2} \times$ scalar & Tutschulte (1976) \\
\hline Scalar for maximum density & Less suitable: 0.75 , suitable: 1 & \\
\hline \multicolumn{3}{|l|}{ Growth } \\
\hline Settlement size & $0.3 \mathrm{~mm}$ & L. Rogers-Bennett (unpubl. data) \\
\hline Maximum first-month size & $1.2 \mathrm{~mm}$ & 36 d; Leighton (1972) \\
\hline Size at maturity & $88-134 \mathrm{~mm}$ & Tutschulte (1976) \\
\hline Maximum size & $250 \mathrm{~mm}$ & Cox (1960) \\
\hline$K$ (von Bertalanffy) & Scalar $\times\left(0.01 \pm 0.03 \mathrm{mo}^{-1}\right)$ & Tutschulte (1976) \\
\hline Scalar for $K$ & $\begin{array}{l}1.25 \text { for } 15-23^{\circ} \mathrm{C} \text {; linearly decreasing to } 0 \text { for } \\
10-15^{\circ} \mathrm{C} \text { or } 23-28^{\circ} \mathrm{C} \text {, } 0 \text { for }<10^{\circ} \mathrm{C} \text { or }>28^{\circ} \mathrm{C}\end{array}$ & \\
\hline$L_{\infty}$ (von Bertalanffy) & 273.86 & Tutschulte (1976) \\
\hline Initial size structure & $\begin{array}{l}0.03 \text { for } 90-130 \mathrm{~mm}_{i} 0.04 \text { for } 100-110 \mathrm{~mm}_{i} \\
0.1 \text { for } 110-120 \mathrm{~mm}_{i} 0.17 \text { for } 120-130 \mathrm{~mm}_{i} \\
0.23 \text { for } 130-140 \mathrm{~mm}^{0} 0.19 \text { for } 140-150 \mathrm{~mm}_{i} \\
0.14 \text { for } 150-160 \mathrm{~mm} ; 0.07 \text { for } 160-170 \mathrm{~mm} ; \\
0.04 \text { for } 170-180 \mathrm{~mm}_{i} 0.01 \text { for } 180-190 \mathrm{~mm}\end{array}$ & $\begin{array}{l}\text { Averaged between } 2002 \text { and } 2010 \\
\text { at Tanner Bank, CA; Stierhoff et } \\
\text { al. (2012) }\end{array}$ \\
\hline \multicolumn{3}{|c|}{ 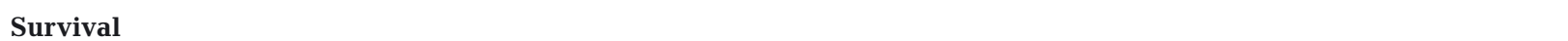 } \\
\hline Larval survival $\left(S_{\mathrm{L}}\right)$ & $\begin{array}{l}0.000015 \text { for } 16-18^{\circ} \mathrm{C} \text {; linearly decreasing to } \\
0 \text { for }<10^{\circ} \mathrm{C} \text { or }>20^{\circ} \mathrm{C}\end{array}$ & $\begin{array}{l}\text { Leighton (1972), Hobday \& } \\
\text { Tegner (2000) }\end{array}$ \\
\hline Post-settlement natural mortality $(M)$ & $\begin{array}{l}0.06 \text { for }<90 \mathrm{~mm} ; 0.01 \text { for } 90-180 \mathrm{~mm}_{i} \\
0.02 \text { for } \geq 180 \mathrm{~mm}\end{array}$ & $\begin{array}{l}\text { Haliotis rufescens; Tegner \& } \\
\text { Butler (1985), Davis (1995) }\end{array}$ \\
\hline Scalar for mortality & $\begin{array}{l}1 \text { for }<18^{\circ} \mathrm{C} \text {, linearly increasing for } \geq 18^{\circ} \mathrm{C} \text {, } \\
\text { up to } 1.5 \text { for } 25^{\circ} \mathrm{C}\end{array}$ & \\
\hline Larval settlement success $(R)$ & Scalar $\times R_{i} R \%=(-377.14)+53.64 T-1.52 T^{2}$ & Leighton (1972) \\
\hline Scalar for larval settlement & $\begin{array}{l}1 \text { for cells with } 0.5 \text { maximum density, linearly } \\
\text { decreasing to } 0 \text { at the maximum density }\end{array}$ & Hobday \& Tegner (2002) \\
\hline \multicolumn{3}{|l|}{ Reproduction } \\
\hline Maturity & $\begin{array}{l}0 \text { for }<88 \mathrm{~mm}, 1 \text { for }>134 \mathrm{~mm} \\
0.85 \text { for } 88-134 \mathrm{~mm}\end{array}$ & \\
\hline Spawning season & February to April & Hobday \& Tegner (2000) \\
\hline Fecundity $(F)$ & $\begin{array}{l}\text { Number of eggs per gram female } \times W \times \\
\text { habitat scalar } \times \text { temperature scalar }\end{array}$ & \\
\hline Body weight $(W)$ & $\ln (W)=4.0243 \ln (L)-14.5069$ & Tutschulte (1976) \\
\hline Number of eggs per gram female & 9052 & Tutschulte (1976) \\
\hline Temperature scalar for fecundity & 0.6 & \\
\hline Habitat scalar for fecundity & Less suitable: 1 , suitable: 1.25 & \\
\hline Fertilization success $(G)$ & $\ln (G \%)=4.32-0.21 d$ & $\begin{array}{l}\text { Haliotis laevigata; } \\
\text { Babcock \& Keesing (1999), Coates } \\
\text { \& Hovel (2014) }\end{array}$ \\
\hline Fertilization radius $(h)$ & $4 \mathrm{~m}$ & $\begin{array}{l}\text { Haliotis laevigata; } \\
\text { Babcock \& Keesing (1999), } \\
\text { Hobday \& Tegner (2002) }\end{array}$ \\
\hline Dispersal radius & $1000 \mathrm{~km}$ & L. Rogers-Bennett (unpubl. data) \\
\hline \multicolumn{3}{|l|}{ Temperature } \\
\hline Optimum larval survival & $16-18^{\circ} \mathrm{C}$ & Leighton (1972) \\
\hline Optimum adult survival & $<18^{\circ} \mathrm{C}$ & L. Rogers-Bennett (unpubl. data) \\
\hline Optimum larval settlement & $16-20^{\circ} \mathrm{C}$ & Leighton (1972) \\
\hline Optimum growth & $15-23^{\circ} \mathrm{C}$ & Leighton (1974) \\
\hline Reduced sperm production & Annual $>18^{\circ} \mathrm{C}$ & Rogers-Bennett et al. (2010) \\
\hline
\end{tabular}

abalone was collected, and were supported by a study that used a bomb radiocarbon dating technique (Andrews et al. 2013). Negative growth was not per- mitted in the model. Any random draws with negative $K$ values were discarded, and we continued until a positive $K$ value was obtained. 

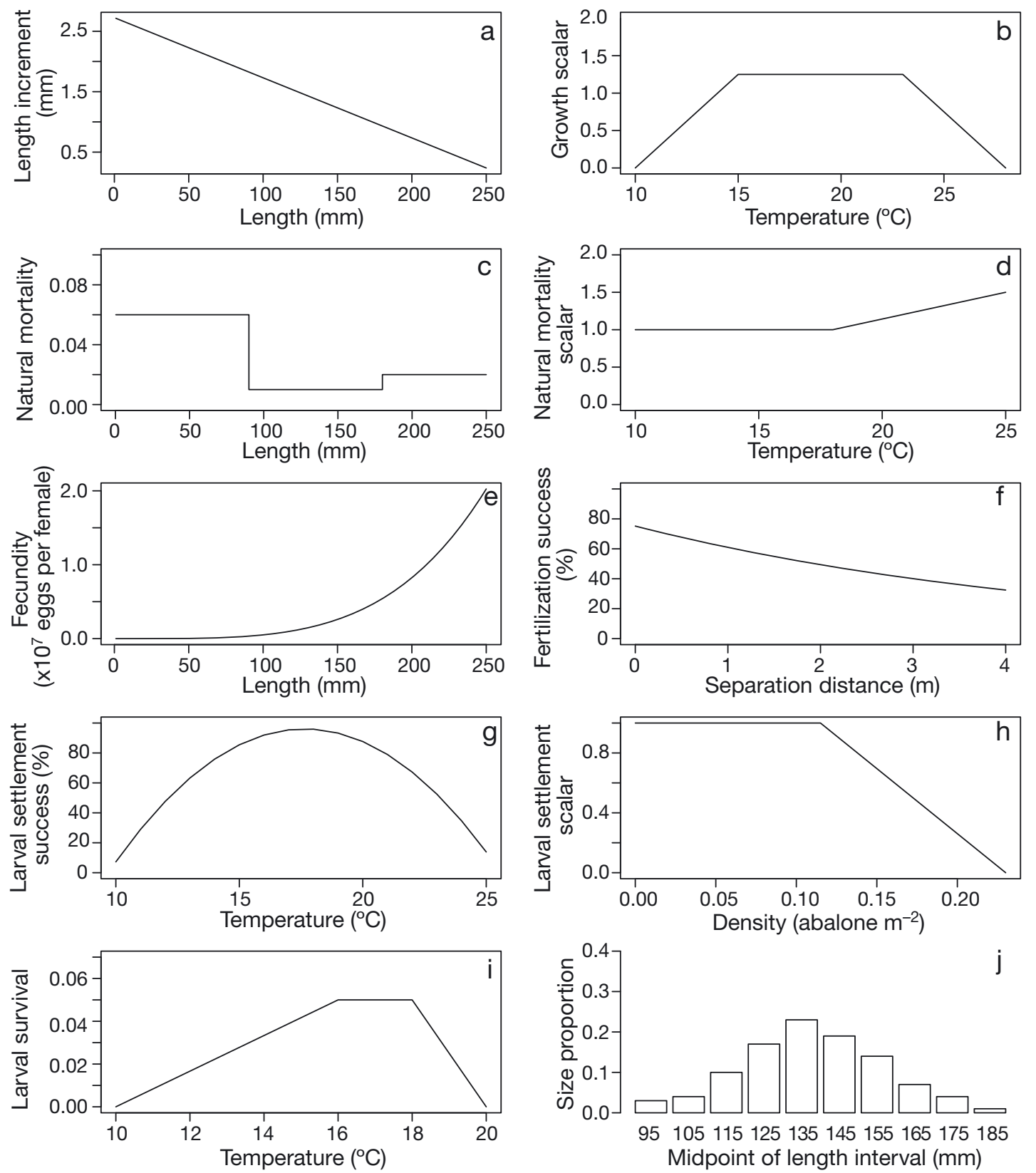

Fig. 3. Changing patterns of parameter values used in the model. See the 'Methods' and Table 1 for more details of the parameters and their calculation

Optimum growth for congeners of white abalone has been reported at 15 to $23^{\circ} \mathrm{C}$, and lower or higher temperature decreases the growth rate (Leighton 1974). In the model, temperature influenced $K$, decreasing it in months with a temperature below $15^{\circ} \mathrm{C}$ or above $23^{\circ} \mathrm{C}$, according to a scalar ranging from 0 to 1.25 (Fig. 3b; Hobday \& Tegner 2002). Thus, the value for $K$ was 0 at low $\left(<10^{\circ} \mathrm{C}\right)$ or high $\left(>28^{\circ} \mathrm{C}\right)$ temperatures, and was 1.25 times the 'normal $K^{\prime}$ at the optimum temperature for growth.

\section{Survival}

Natural mortality generally declines with age for abalone (Tegner \& Butler 1985, Shepherd \& Daume 1996, Leaf et al. 2007). In this study, we assumed the post-settlement monthly natural mortality $(M)$ for abalones smaller than $90 \mathrm{~mm}$, abalones between 90 and $180 \mathrm{~mm}$, and abalones larger than $180 \mathrm{~mm}$ to be $0.06,0.01$, and 0.02 , respectively. The mortality rates for young and adult abalone were calculated based 
on an annual survival estimate for juvenile (Tegner \& Butler 1985, Davis 1995) and adult (Tegner 1989) red abalone Haliotis rufescens. We increased the natural mortality for old abalone to simulate the senescence of individuals (Fig. 3c; Vetter 1988, Hampton 2000, Tang 2012). The post-settlement monthly survival rate $S$ was calculated as:

$$
S=\exp (-M)
$$

Each month, each abalone was randomly assigned a value of 0 or 1 , which was generated from a Bernoulli distribution with a success probability of $S$. Individuals that received a value of 1 would survive to the end of that month, and those that received a value of 0 would die.

In laboratory observations, mortality of adult white abalone occurred when temperature exceeded 18 to $19^{\circ} \mathrm{C}$. In the model, for months with a temperature $>18^{\circ} \mathrm{C}$, higher temperature linearly increased the mortality rate $M$ by up to $50 \%$, i.e. the mortality was $M$ at temperatures below $18^{\circ} \mathrm{C}$, and linearly increased from $M$ at $18^{\circ} \mathrm{C}$ to $1.5 \times M$ at $25^{\circ} \mathrm{C}$ (Fig. $3 \mathrm{~d}$ ).

\section{Reproduction}

Abalone were assumed to spawn during February through April (Tutschulte 1976, Hobday \& Tegner 2000). Each individual was randomly determined to spawn in 1 of the 3 spawning months. Abalone fecundity is related to size, and in the model, the size-specific fecundity ( $F$, number of eggs per female, Fig. 3e) was derived from a study on fecundity of wild female white abalone with the relationship between shell length and body weight (Tutschulte 1976):

$$
\begin{gathered}
F=f \times W \\
\ln (W)=4.0243 \ln (L)-14.5069
\end{gathered}
$$

where $W$ is body weight $(\mathrm{g})$ of individuals, and $f=$ 9052 is the mean number of eggs per gram of female body weight. Fecundity was also influenced by temperature and habitat quality. In the model, the value for $f$ was reduced by $40 \%$ when the annual average water temperature was $>18^{\circ} \mathrm{C}$, and was also adjusted by multiplying a scalar of 1 or 1.25 according to the habitat quality (Fig. 1).

Fertilization success was described by a fertilization radius ( $h=4 \mathrm{~m}$; Babcock \& Keesing 1999) of a female and a separation distance $(d)$ from the female to each male (Hobday \& Tegner 2002). An exponential decay relationship (Coates \& Hovel 2014) was derived using the field estimates from Babcock \& Keesing (1999). This relationship assumed that the males farther away from the female would contribute less to fertilizing eggs (Fig. 3f):

$$
\ln (G \%)=4.32-0.21 d
$$

Males within the fertilization radius were ranked by their distance to the female, and the number of eggs fertilized was calculated individually through the rank. For example, the closest male would fertilize eggs first with a fertilization success of $G$ (Eq. 4); the remaining eggs would be fertilized by the second closest male with a fertilization success of $G$; this calculation would continue until all subsequent males were evaluated. Those males outside this fertilization radius would not participate in fertilizing the eggs produced by this female. The total number of fertilized eggs was obtained by summing the contribution of each male within the fertilization radius. Adult abalones have limited movement after larvae disperse and settle to a suitable habitat (Shepherd 1973, Tutschulte 1976, Hobday \& Tegner 2000). Therefore, the model did not incorporate adult movement or aggregation after settlement, and assumed a 100\% spawning synchrony between each female and the males within the fertilization radius.

\section{Larval survival, dispersal, and settlement}

Larval survival of white abalone has been assumed to be low (Hobday \& Tegner 2000), and was reported to be best at $16-18^{\circ} \mathrm{C}$, and 0 below $10^{\circ} \mathrm{C}$ or above $20^{\circ} \mathrm{C}$ (Leighton 1972). In the model, larval survival $\left(S_{\mathrm{L}}\right)$ decreased linearly from 0.000015 at $16-18^{\circ} \mathrm{C}$ to 0 at $10^{\circ} \mathrm{C}$ and at $20^{\circ} \mathrm{C}$ (Fig. 3i).

The likely scale of dispersal is less than $100 \mathrm{~km}$ for abalone larvae that are close to the bottom with a larval duration of $7 \mathrm{~d}$ based on a dispersal model simulation for red abalone (Rogers-Bennett et al. $2016 b)$. White abalone in the wild may have a longer larval duration of 8 to $10 \mathrm{~d}$ (Leighton 1972, L. RogersBennett unpubl. data), and thus longer dispersal is likely for white abalone in the wild. In the model, we set the larval dispersal radius to be $100 \mathrm{~km}$. This radius covered the whole modeled area in the case of white abalone, and thus, dispersal did not play a role in this particular application of the model. Space within this radius around a female was available for the larvae produced by this female to settle. In the model, we assumed all larvae settled within the modeled space even when the spawning female was located near a border. Future applications of the model may vary the dispersal distance to make it play a significant role in the outcome of the model. 
Larval settlement success was found to be high at 16 to $20^{\circ} \mathrm{C}$ and 0 at a temperature below $10^{\circ} \mathrm{C}$ (Leighton 1972). In the model, we adopted the relationship between settlement success $R(\%)$ and temperature $T\left({ }^{\circ} \mathrm{C}\right)$ from Leighton (1972), i.e. we digitized the data and re-estimated the relationship using a second-order polynomial curve (Fig. 3g):

$$
R \%=-377.14+53.64 T-1.52 T^{2}
$$

In the model, larval settlement success also depended on the density of the cell where the larvae were going to settle, with a factor of 1 at half the maximum density declining to 0 at the maximum density (Fig. 3h; Hobday \& Tegner 2002). The total number of settled larvae $\left(N_{L}\right)$ within the dispersal radius (the whole modeled area for white abalone in this study) was:

$$
N_{L}=Q \times S_{\mathrm{L}} \times R^{\prime}
$$

where $Q$ is the total number of fertilized eggs, and $R^{\prime}$ is the settlement success (\%) scaled by the maximum density of a cell as described above.

In this model, larvae settled at random locations within the dispersal radius of the spawning female (across all habitat cells in the modeled area for white abalone), and settlement was not influenced by the presence of adults. Sex was randomly assigned to each settled abalone with a 1:1 sex ratio, as observed for white abalone (Tutschulte 1976, Hobday \& Tegner 2000). A size between settlement size $(0.3 \mathrm{~mm})$ and maximum first-month size $(1.2 \mathrm{~mm})$ was randomly given to each settled abalone, which simulated continuous growth within the first month after settlement (Hobday \& Tegner 2002). Settlement would not be allowed when the overall density of residents within a habitat cell reached the maximum density of the cell (carrying capacity, as defined in the next subsection). Spatial distribution of individuals was only constrained by the maximum density of the cell, and thus, 2 abalone could be 0 to $10 \mathrm{~m}$ apart from one another within a cell. Settlement success was also assumed to decline linearly from $R$ at half the maximum resident density to 0 at the maximum density (Hobday \& Tegner 2002). This densitydependent settlement success represented intraspecific competition due to space and resource limitation.

\section{Maximum density}

The estimated density for the wild white abalone population before fishery collapse (i.e. before 1978) was poorly assessed. The density estimates are highly variable due to survey methodology limitations and local variation (Hobday \& Tegner 2000), ranging from a minimum possible estimate of $0.0479 \mathrm{~m}^{-2}$ over a broad geographic area (RogersBennett 2002) to $0.23 \mathrm{~m}^{-2}$ for a high-density patch (Tutschulte 1976). In this study, we set the maximum density to be 0.23 abalone $\mathrm{m}^{-2}$. This maximum density was set to decline in areas of poor habitat quality, i.e. the maximum density for suitable and less suitable habitats was calculated by multiplying the normal maximum density by a scalar of 1 and 0.75, respectively. Biologically, this model assumption represented the higher carrying capacity (e.g. food resource) in the better habitat.

\section{Model initialization and replication}

Initial size for each individual (Fig. 3j, Table 1) was assigned based on the size structure of the population from a survey conducted between 2002 and 2010 at Tanner Bank, California (Stierhoff et al. 2012). Each abalone in the initial population was randomly assigned a sex with a 1:1 sex ratio. Ten replicates for each run were made. Each model run was simulated by monthly time steps for $100 \mathrm{yr}$, and the population characteristics (e.g. population size/density, length structure, recruitment) were updated each month. The model simulation flowchart is presented in Fig. 4.

We determined the number of resident abalone and the number of stocked juveniles for our simulations through a sensitivity analysis. We tested combinations of 500 residents with 500 stocked abalone, 800 residents with 800 stocked abalone, and 1000

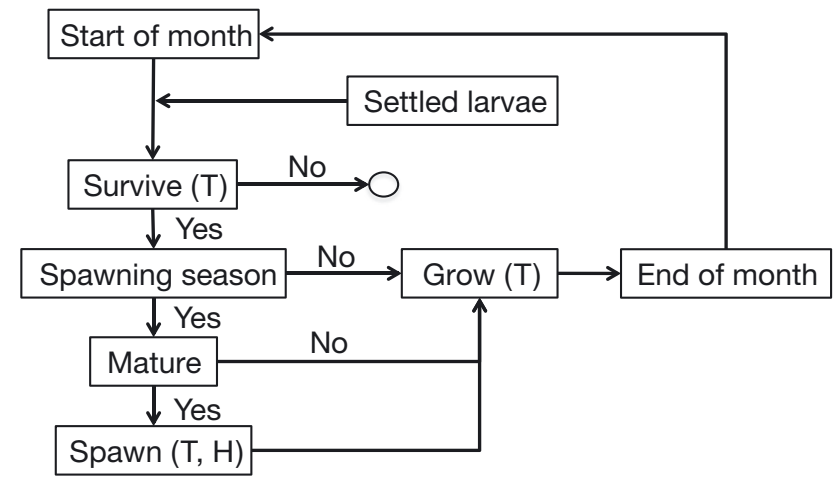

Fig. 4. Flowchart for the individual-based model of white abalone Haliotis sorenseni. $\mathrm{T}$ or $\mathrm{H}$ in parentheses indicates that impact of temperature or habitat quality, respectively, was specifically incorporated in the model 
residents with 1000 stocked abalone. This sensitivity analysis was conducted under each of the scenarios listed in the following section except the poaching scenario. We decided to use the combination of 500 residents with 500 stocked abalone because the total number of individuals in the modeled space cannot reach the carrying capacity at any time during the simulation. Otherwise, we would not be able to observe the population dynamics in response to our model manipulations because the output would be constrained by the carrying capacity.

\section{Model scenarios and interpretation}

With the model, we conducted simulations to evaluate hypothetical stocking strategies and to investigate the impacts of habitat spatial structure and warming ocean temperature on the stocking strategies. Stocking strategy scenarios included: (1) stocked abalone randomly distributed or clustered $(70 \%$ stocked abalone in suitable habitat and $30 \%$ in less suitable habitat; randomly distributed within each habitat type); (2) there were no initial residents or 500 initial residents at the time of stocking; (3) stocked abalone were 20,40 , or $80 \mathrm{~mm}$ in shell length. Habitat spatial structure scenarios included: (1) $50 \%$ suitable habitat or $30 \%$ suitable habitat, and (2) habitat cells were distributed randomly or in clusters; specifically, $50 \%$ suitable and $50 \%$ less suitable habitat were randomly distributed or clustered (suitable habitat cells in the center of the region surrounded by less suitable habitat cells around the periphery); $30 \%$ suitable and $70 \%$ less suitable habitat were randomly distributed or clustered; the spatial distribution of suitable and less suitable habitat was fixed between model runs for each scenario (Fig. 1). In the warming ocean temperature scenarios, we elevated the annual average temperature by $3^{\circ} \mathrm{C}$ (Fig. 2).

Poaching has been a great concern for endangered marine species (Crowder et al. 1994), and thus in this study, we also explored the impacts of poaching on stocking strategies. We implemented poaching by taking $10 \%$ of large abalone $(\geq 80 \mathrm{~mm}$ ) every year (at the beginning of each year) in scenarios where $50 \%$ suitable and $50 \%$ less suitable habitat cells were randomly distributed. Abalone with sizes of 20,40, and $80 \mathrm{~mm}$ were stocked at normal and high temperatures with 500 initial resident abalone, and $70 \%$ stocked abalone were distributed in suitable habitat and $30 \%$ in less suitable habitat. Under each scenario, we ran the model for $100 \mathrm{yr}$, and tracked the population size and recruitment over time.
The White Abalone Recovery Plan (NMFS 2008) gives detailed quantitative downlisting criteria as white abalone recover that can be evaluated using this model. The Recovery Plan requires a minimum density of $>2000$ ind. ha ${ }^{-1}$ and a minimum proportion of $85 \%$ intermediate-size individuals $(90-130 \mathrm{~mm})$ for white abalone to be downlisted. Thus, we also tracked the proportion of intermediate-size abalone (90-130 $\mathrm{mm}$ ) over time under each scenario.

In this study, we did not have data to validate the individual-based model for white abalone, a problem which is typical for endangered species. In some species with abundant data, the performance of the model can be validated (Grimm 1999). For example, Chang et al. (2010) evaluated an individual-based model by comparing the modeled seasonal size distribution with the observed distribution for landed lobsters. Thus, due to data limitations in the case of white abalone, we interpreted our model results in a relative way, as suggested by Beissinger \& Westphal (1998), instead of focusing on the absolute values of the quantity of interest under each scenario. In this way, we examined the model scenarios that yielded the best recovery results relative to the other scenarios.

\section{RESULTS}

Model results for the scenarios with stocked abalone randomly distributed were similar to those for the scenarios with stocked abalone in clustered distributions. Thus, in this paper, we only show the results of the latter scenarios because typically animals are clustered when first stocked.

\section{Efficacy of stocking strategies}

The model runs with 500 initial resident abalone compared with no resident runs yielded a larger population size, a higher proportion of intermediatesized individuals, and a higher recruitment, with a slower decline, especially at normal temperature (Figs. 5-7). The intermediate-size proportion in these scenarios was stabilized at a level of approximately $10 \%$ of the population under normal temperatures (Fig. 7).

Stocking larger-sized abalone was more efficient in terms of boosting population size and recruitment, especially at normal temperatures (Figs. $5 \& 6$ ). When there were no initial residents, stocking larger abalone also produced a higher proportion and a more stable intermediate-size class in the population 

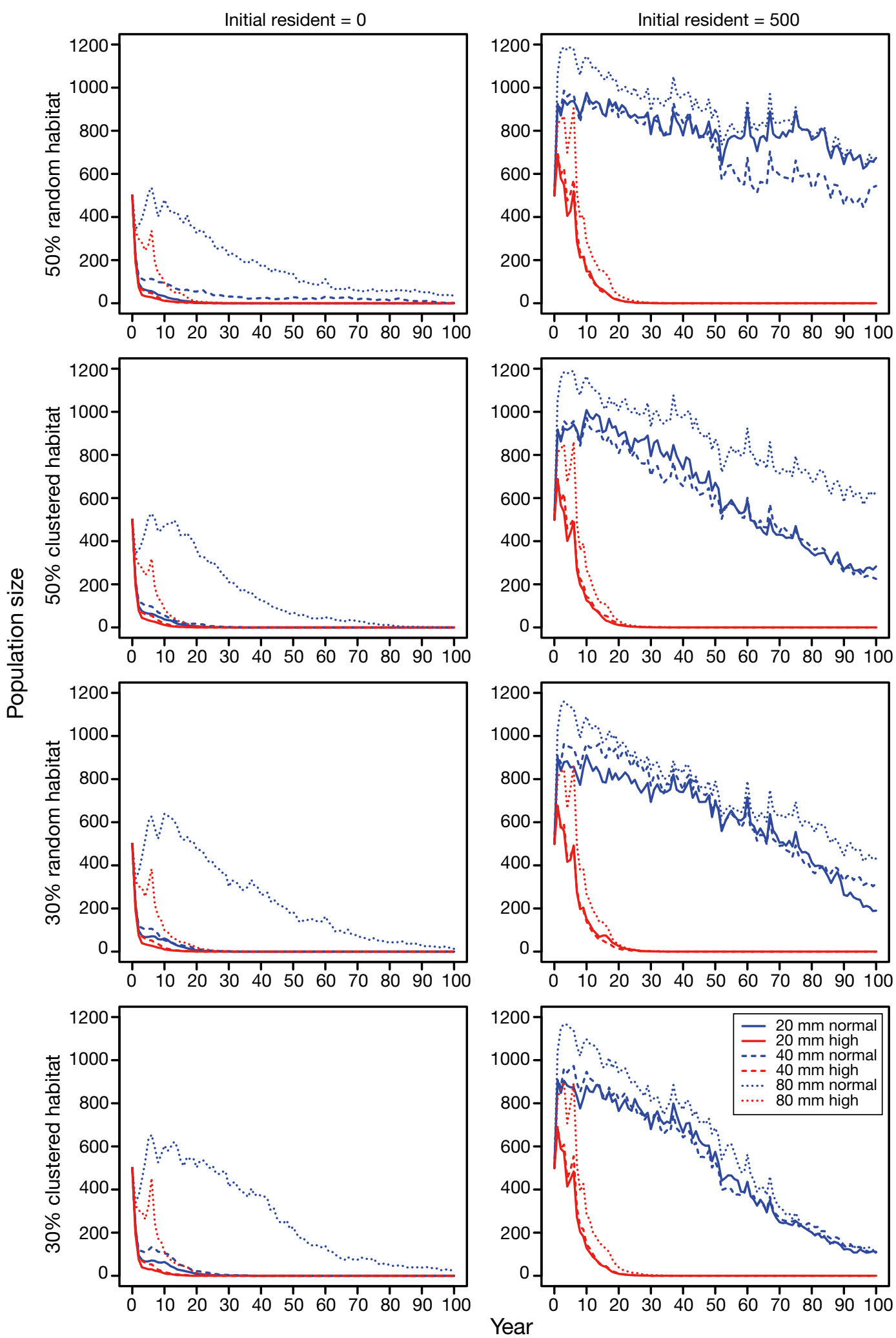

Fig. 5. Simulated population size of white abalone Haliotis sorenseni when $70 \%$ stocked abalone are distributed in suitable habitat and $30 \%$ in less suitable habitat (rows 1-4). Results show stocking 20, 40, and $80 \mathrm{~mm}$ abalone at normal and high temperature with 0 (left column) and 500 initial resident abalone (right column). Habitats are configured with randomly distributed (rows 1 and 3) or clustered (rows 2 and 4) habitat cells, and with 50\% (rows 1 and 2) or 30\% (rows 3 and 4 ) suitable habitat. The simulation was run for $100 \mathrm{yr}$ 

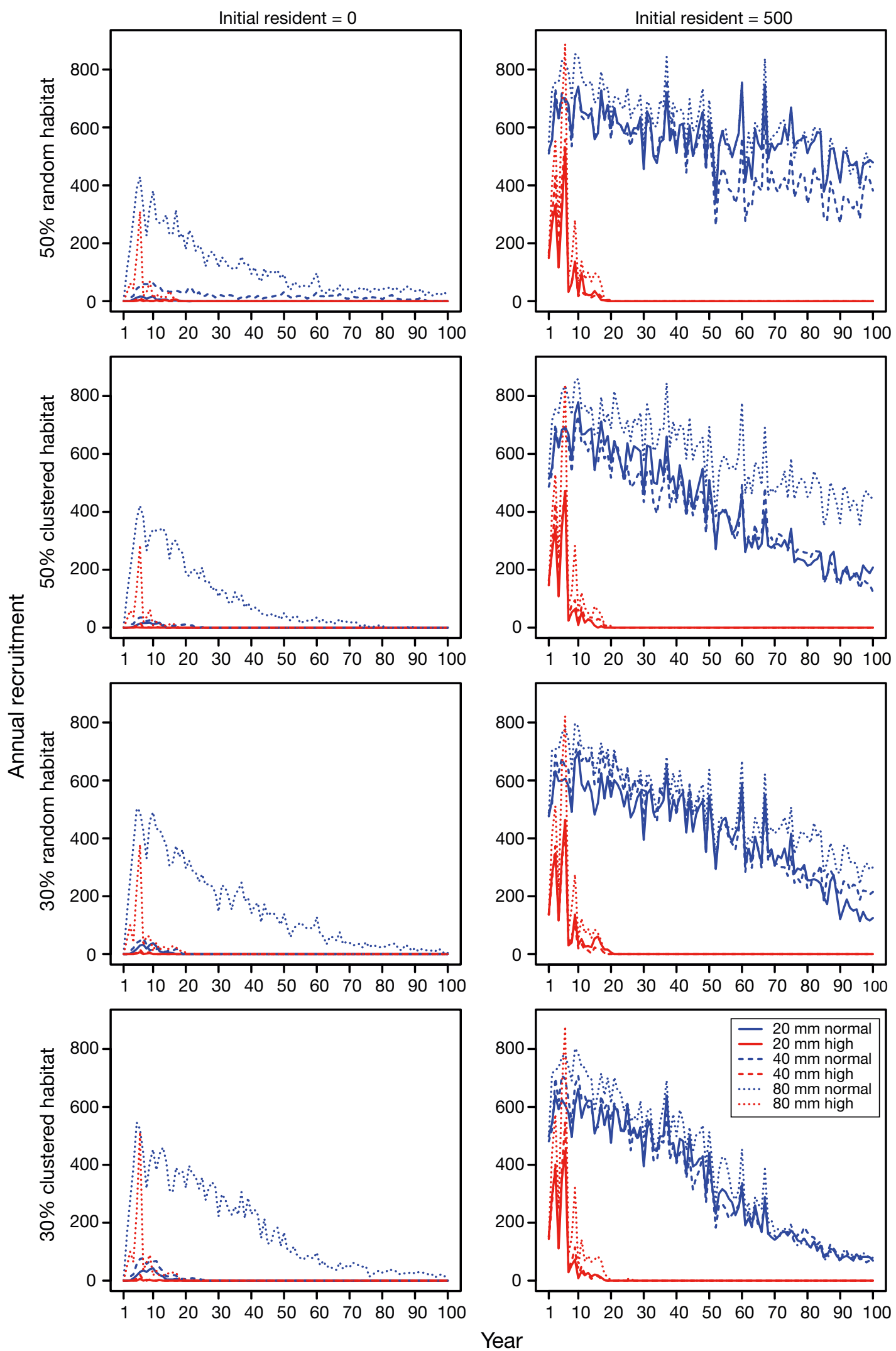

Fig. 6. Simulated recruitment of white abalone Haliotis sorenseni. All parameters as in Fig. 5 

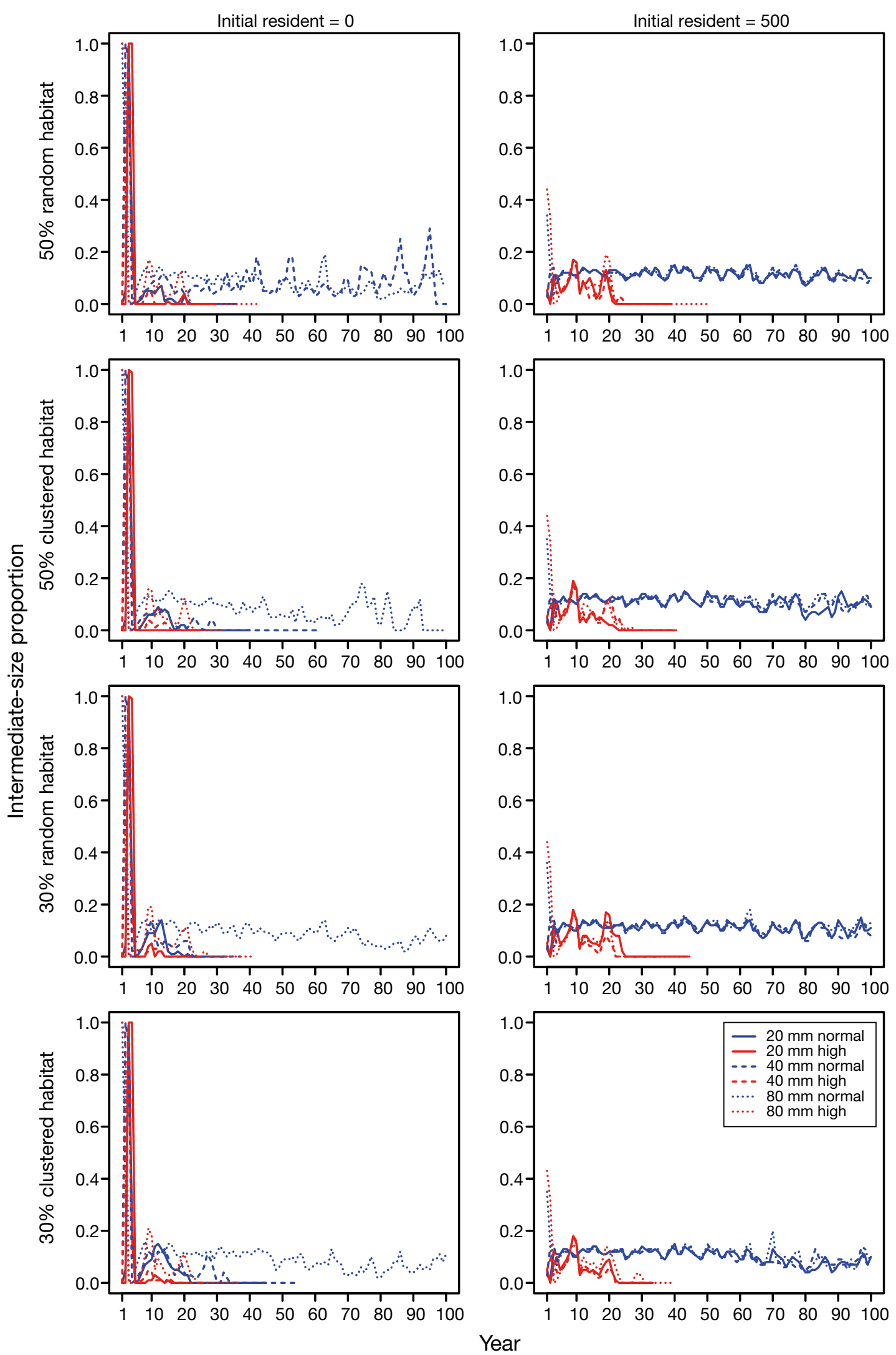

Fig. 7. Simulated intermediate-size proportion of white abalone Haliotis sorenseni. All parameters as in Fig. 5 
than stocking smaller abalone (Fig. 7). However, size of the stocked abalone had little impact on intermediate-size proportion in the scenarios with 500 resident abalone.

\section{Influence of habitat spatial structure and warming ocean temperature on stocking strategies}

The percentage of suitable habitat $(50 \%$ versus $30 \%$ ) showed less of an impact on population dynamics in the scenarios with no initial residents, compared to the scenarios with 500 initial resident abalone. In the scenarios with 500 initial residents, more suitable habitat resulted in a longer time period with a sustained population (i.e. a slower decrease in population size and recruitment), and a slightly higher proportion of intermediate-size abalone (Fig. 7). Spatial distribution of habitat cells (i.e. random versus clustered) did not greatly affect population size (Fig. 5) and intermediate-size proportion (Fig. 7), but did influence recruitment. Recruitment decreased more slowly in the habitats with randomly distributed habitat cells than in those with clustered habitat cells (Fig. 6).

Model runs with higher temperatures resulted in a faster decrease in population size, intermediate-size proportion, and recruitment. Higher temperatures in the model led to population extinction $80 \mathrm{yr}$ sooner for all stocked sizes even when the initial resident population was present. The responses of abalone populations to elevated temperatures became more obvious in the scenarios with 500 initial residents (Figs. 5-7). Under optimal temperatures, when the resident population was locally extinct, the largest stocked abalone $(80 \mathrm{~mm})$ persisted at least $80 \mathrm{yr}$ longer than in other scenarios, highlighting the importance of temperature for persistence.

\section{Impacts of poaching on stocking strategies}

Poaching imposed serious threats to the success of restoration strategies in our model population, especially in the high-temperature scenarios (Fig. 8). Compared to the scenarios without poaching (plots in the first row, right column of Figs. 5-7), when poaching occurred every year, the modeled white abalone population declined dramatically and went extinct at least $70 \mathrm{yr}$ sooner under normal temperature and 10 yr sooner under high temperature, compared to the scenarios without poaching at normal and high temperatures, respectively; the annual population
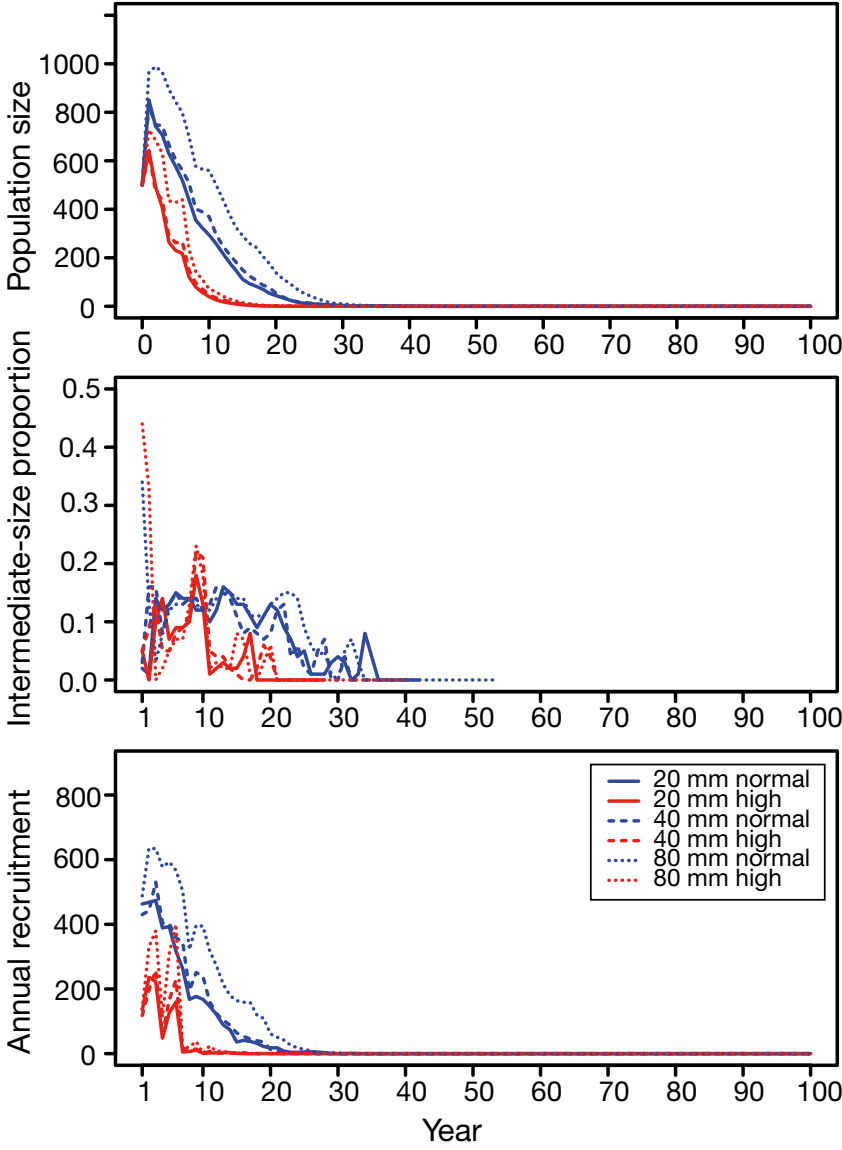

Fig. 8. Simulated population size, intermediate-size proportion, and recruitment of white abalone Haliotis sorenseni when $10 \%$ of large abalone ( $\geq 80 \mathrm{~mm}$ ) are poached (illegally taken) every year. In this illustration, 50\% suitable and 50\% less suitable habitat cells were randomly distributed, abalone with sizes of 20,40 , and $80 \mathrm{~mm}$ were stocked at normal and high temperatures with 500 initial resident abalone, and $70 \%$ stocked abalone were distributed in suitable habitat and $30 \%$ in less suitable habitat. The simulation was run for $100 \mathrm{yr}$

size was approximately $20 \%$ smaller (Fig. 8). Poaching led to a decline in intermediate-size proportion and a sharp drop in annual recruitment, with recruitment being reduced to 0 within $30 \mathrm{yr}$. Poaching cut annual recruitment by $25 \%$ under normal temperatures and nearly halved the annual recruitment under the high-temperature scenario.

\section{DISCUSSION}

\section{Factors influencing restoration strategies}

There is an increasing awareness of the importance of spatial structure in population dynamics 
and fisheries management (e.g. Booth 2000, Hutchings 2000, Lorenzen et al. 2010). Inclusion of the spatial dynamics in fishery and conservation evaluations can help elucidate metapopulation structure (Lipcius et al. 2008, Secor et al. 2009, Ying et al. 2011), movement, and migratory patterns (Goethel et al. 2011), as well as aid in restoration planning for endangered species. Ignoring spatial structure of the habitat or the population may lead to erroneous estimates of population abundance and species' life history parameters (Swartzman et al. 1992, Booth 2000, Ying et al. 2011), and may even lead to failed management or restoration actions (Hutchings 2000, Hutchinson 2008). In this study, we explored the spatial structure of habitat (percentage of suitable habitat and spatial distribution of habitat cells) and the spatial structure of the population (random or clustered distribution of stocked abalone), contributing to the body of work that explores the importance of spatial structure in population dynamics and conservation.

Spatial structure of the habitat influences the population spatial structure by providing a mosaic of suitable habitat, movement passages, and spatially heterogeneous resources (Dunning et al. 1992, Wiens et al. 1993). Populations may also be spatially structured as a result of dispersal and movement of individuals at certain life stages (Dieckmann et al. 1999). In the case of white abalone, larval dispersal is a source of structuring populations in space, but this was not explicitly explored in our model. Stocking strategies (e.g. where and how to distribute stocked juvenile abalones) may also contribute to the population spatial structure because abalones have limited movement after settlement (Shepherd 1973, Tutschulte 1976, Hobday \& Tegner 2000). Although in our simulation, spatial distribution of stocked juveniles showed little impact, studies have indicated that long-lived species are more likely to be influenced by the population spatial structure, e.g. Atlantic cod Gadus morhua (Hutchings 2000) and red king crab Paralithodes camtschaticus (Orensanz et al. 1998). Thus, population spatial structure of a longlived endangered species should be evaluated in making restoration strategies.

The White Abalone Recovery Plan (NMFS 2008) establishes downlisting criteria based on both density and size structure (the proportion of intermediate-sized, 90-130 mm abalone) which can be evaluated using a modeling framework. Our modeling study showed that the presence of an initial resident population in the habitat had a positive impact on the restoration outcomes compared with no initial white abalone in the habitat (Figs. 5-7). This result suggested that even a low number of abalone (e.g. $500 \mathrm{ha}^{-1}$ in this study), below the minimum population size required for downlisting $\left(2000 \mathrm{ha}^{-1}\right.$; NMFS 2008) is far better for restoration compared with a habitat from which the species has already gone locally extinct. Due to the failure of reproduction and poor recruitment in wild populations resulting from low density, wild populations are likely dominated by older adults. Stocking juveniles $(40-80 \mathrm{~mm})$ to the population may help balance the size distribution and better sustain the population by providing animals for future reproduction. Also, as shown in this study, stocking larger juveniles may modify population size/density but had little effect on the proportion of intermediate-sized individuals. Only stocking at normal temperatures combined with stocking at a location with an initial resident population led to a consistent proportion of intermediate-sized abalone (Fig. 7). These results highlight the importance of starting restoration actions sooner rather than later before there are no abalone left in the stocking areas.

In the model, temperature played an extremely important role in modifying the population dynamics and restoration efficacy of white abalone. It also poses a challenge to white abalone restoration under a changing climate, with a warmer ocean temperature predicted for the California coast (Hoegh-Guldberg et al. 2007). With only a $3^{\circ} \mathrm{C}$ elevation in annual average temperature in the model, endangered abalone populations went extinct 80 yr earlier.

According to our model results, stocking larger juveniles enhanced the model populations, even at locations with initially no resident abalone (Figs. 5-7). The benefit of stocking larger abalone has been recognized in other studies (e.g. RogersBennett \& Leaf 2006, Li \& Jiao 2015). However, in practice, raising juveniles in the hatchery to larger sizes before stocking increases the costs and may reduce the ability of stocked animals to adapt to the wild environment (NMFS 2008, Straus \& Friedman 2009). Using the growth parameters under the most suitable temperature $\left(15-23^{\circ} \mathrm{C}\right)$ in this study as an example, juvenile abalone would reach the largest stocked size that we tested $(80 \mathrm{~mm})$ at around $4 \mathrm{yr}$ of age. Thus, restoration efforts need to balance the efficacy of stocking larger abalone with the additional time/hatchery costs.

Poaching had a major negative impact on the model white abalone population, with $10 \%$ poaching every year resulting in recruitment failure and accelerating population extinction. Abalone poach- 
ing has been a global concern threatening the sustainability of abalone fisheries worldwide (Hauck \& Sweijd 1999, Jamieson 2001, Huchette \& Clavier 2004, Rogers-Bennett \& Melvin 2007). In California, where the recreational red abalone fishery north of San Francisco is the only abalone fishery open in the state, thousands of wild red abalone are unlawfully sold every year (Daniels \& Floren 1998, Gordon \& Cook 2004, Rogers-Bennett \& Melvin 2007). In South Africa, illegal take of abalone could be as great as legal take, which raises socioeconomic and political conflict, and imposes great challenges for cooperative fisheries management (Hauck \& Sweijd 1999, Tarr 2000). Any restoration plan will need to make careful recommendations to prevent poaching, since this alone could lead to failure of restoration efforts contributing to the extinction of the species.

\section{Assumptions and interpretation of the model}

Although our model was developed for hypothetical space, we aimed to provide a modeling framework that can easily be applied to an actual habitat location, making the model spatially explicit. Developing such a spatially explicit model, we will need to define the boundaries of habitat cells and to determine the habitat quality for each cell. In the case of white abalone, suitable habitat can be determined based on geomorphic (e.g. flat seafloor covered with sand) and ecological (e.g. abundant brown algae) features (Hobday \& Tegner 2000, Butler et al. 2006), as well as ocean temperature and existing resident density.

We expected the spatial distribution of habitat cells (i.e. random or clustered) to be as important as the percent of suitable habitat in influencing the population dynamics of abalone. However, our study did not support this hypothesis (Figs. 5-7). One possible reason may be that the differences between suitable and less suitable habitats defined in our model (e.g. the scalar of 1 for suitable habitat versus 0.75 for less suitable habitat) were not big enough to lead to large differences in model outcomes. A series of model runs with different habitat scalars could be used in future studies to further test this hypothesis.

We did not incorporate larval dispersal in our model. The model does allow for this feature to be added in other applications. We also did not incorporate current-driven larval dispersal. One of the difficulties with modeling this feature is that the ocean current is very dynamic over time, and the modeled time step needs to be small enough (e.g. hourly) to capture its dynamics, which would require more intensive computation, especially for long-lived species like abalone. These features could be further developed in future applications of the model.

\section{CONCLUSIONS}

We developed an individual-based model that explicitly incorporated temperature-, density-, and habitat-dependent life history processes for an endangered marine broadcast spawner. This model provides a framework for evaluating potential restoration strategies under different habitat spatial structure scenarios. Using white abalone in southern California as an example, we demonstrated how we can use this modeling framework and apply it to inform restoration of endangered marine broadcast spawners. Restoration of white abalone would be more successful when starting at a location with resident abalone and stocking larger sized abalone, although stocking efforts need to balance the efficacy of stocking larger abalone with the additional laboratory cost. These results highlight the importance of starting restoration in the ocean before all wild white abalone have died off or are taken illegally. Further, our results showed that stocking abalone inside areas with a higher percentage of suitable habitats yielded more persistent abalone populations compared to scenarios with less suitable habitat; however, the spatial distribution of suitable habitat cells (i.e. random or clustered) and the spatial distribution of stocked abalone (random or clustered) had less effect. The model results highlight 2 major threats for white abalone restoration in the future: (1) ocean warming and (2) poaching, both of which will require careful planning when implementing future restoration strategies.

Acknowledgements. This research was supported by a NOAA Section 6 grant to the California Department of Fish and Wildlife (no. NA10NMF4720024) and to its partner, the University of California, Davis, at the Karen C. Drayer Wildlife Health Center (Contract P1570004). Y.L. was supported as a Postdoctoral Fellow under this contract. L.R.B. was supported by the California Department of Fish and Wildlife. We thank Dr. Cynthia Catton for comments on the modeling work; Ian Taniguchi (CDFW) for support and administering this grant at CDFW; Dr. Kirsten Gilardi of the Karen C. Dreyer Wildlife Health Center at UC Davis for support; and editor Steven Cooke and 2 anonymous reviewers for helping to improve the manuscript. 


\section{LITERATURE CITED}

Andrews AH, Leaf RT, Rogers-Bennett L, Neuman M, Hawk H, Cailliet GM (2013) Bomb radiocarbon dating of the endangered white abalone (Haliotis sorenseni): investigations of age, growth and lifespan. Mar Freshw Res 64: 1029-1039

Babcock R, Keesing J (1999) Fertilization biology of the abalone Haliotis laevigata: laboratory and field studies. Can J Fish Aquat Sci 56:1668-1678

Baker MC, Tyler PA (2001) Fertilization success in the commercial gastropod Haliotis tuberculata. Mar Ecol Prog Ser 211:205-213

Beissinger SR, Westphal MI (1998) On the use of demographic models of population viability in endangered species management. J Wildl Manag 62:821-841

Booth AJ (2000) Incorporating the spatial component of fisheries data into stock assessment models. ICES J Mar Sci 57:858-865

Butler J, Neuman M, Pinkard D, Kvitek R, Cochrane G (2006) The use of multibeam sonar mapping techniques to refine population estimates of the endangered white abalone (Haliotis sorenseni). Fish Bull 104:521-532

Button CA (2008) The influence of density-dependent aggregation characteristics on the population biology of benthic broadcast-spawning gastropods: pink abalone (Haliotis corrugata), red abalone (Haliotis rufescens), and wavy turban snails (Megastraea undosa). PhD dissertation, University of California, San Diego, CA

Catton C, Stierhoff KL, Rogers-Bennett L (2016) Population status assessment and restoration modeling of white abalone Haliotis sorenseni in California. J Shellfish Res 35:593-599

Chang Y, Sun C, Chen Y, Zhang Y, Yeh S (2010) Incorporating climate changes into population dynamic modelling: an individual-based modelling approach for lobster. Can J Fish Aquat Sci 68:122-136

Coates JH, Hovel KA (2014) Incorporating movement and reproductive asynchrony into a simulation model of fertilization success for a marine broadcast spawner. Ecol Model 283:8-18

Cox KW (1960) Review of the abalone of California. Calif Fish Game Bull 46:381-406

Crowder LB, Crouse DT, Heppell SS, Martin TH (1994) Predicting the impact of turtle excluder devices on loggerhead sea turtle populations. Ecol Appl 4:437-445

Daniels R, Floren R (1998) Poaching pressures on northern California's abalone fishery. J Shellfish Res 17:859-862

Davis GE (1995) Recruitment of juvenile abalone (Haliotis spp.) measured in artificial habitats. Mar Freshw Res 46: 549-554

${ }^{*}$ Dieckmann U, O'Hara B, Weisser W (1999) The evolutionary ecology of dispersal. Trends Ecol Evol 14:88-90

Dunning JB, Danielson BJ, Pulliam HR (1992) Ecological processes that affect populations in complex landscapes. Oikos 65:169-175

Goethel DR, Quinn TJ, Cadrin SX (2011) Incorporating spatial structure in stock assessment: movement modeling in marine fish population dynamics. Rev Fish Sci 19:119-136

Gordon HR, Cook PA (2004) World abalone fisheries and aquaculture update: supply and market dynamics. J Shellfish Res 23:935-940

Grimm V (1999) Ten years of individual-based modelling in ecology: What have we learned and what could we learn in the future? Ecol Model 115:129-148
Hampton J (2000) Natural mortality rates in tropical tunas: Size really does matter. Can J Fish Aquat Sci 57: 1002-1010

Hauck M, Sweijd N (1999) A case study of abalone poaching in South Africa and its impact on fisheries management. ICES J Mar Sci 56:1024-1032

*Hawkes LA, Broderick AC, Godfrey MH, Godley BJ (2009) Climate change and marine turtles. Endang Species Res 7:137-154

Hobday AJ, Tegner MJ (2000) Status review of white abalone (Haliotis sorenseni) throughout its range in California and Mexico. US Department of Commerce, National Oceanic and Atmospheric Administration, National Marine Fisheries Service, Southwest Fisheries Science Center, La Jolla, CA

Hobday AJ, Tegner M (2002) The warm and the cold: influence of temperature and fishing on local population dynamics of red abalone. Calif Coop Ocean Fish Invest Rep 43:74-96

Hoegh-Guldberg O, Mumby PJ, Hooten AJ, Steneck RS and others (2007) Coral reefs under rapid climate change and ocean acidification. Science 318:1737-1742

Huchette S, Clavier J (2004) Status of the ormer (Haliotis tuberculata L.) industry in Europe. J Shellfish Res 23: 951-956

Hutchings JA (2000) Collapse and recovery of marine fishes. Nature 406:882-885

* Hutchinson WF (2008) The dangers of ignoring stock complexity in fishery management: the case of the North Sea cod. Biol Lett 4:693-695

Jamieson G (2001) Review of the status of the northern abalone, Haliotis kamtschatkana, in Canada. Can Field Nat 115:555-563

Karpov KA, Haaker PL, Taniguchi IK, Rogers-Bennett L (2000) Serial depletion and the collapse of the California abalone (Haliotis spp.) fishery. In: Campbell A (ed) Workshop on Rebuilding Abalone Stocks in British Columbia. Canadian Special Publications Fisheries and Aquatic Sciences 130, NRC Research Press, Ottawa. p 11-24

Leaf R, Rogers-Bennett L, Haaker PL (2007) Spatial, temporal, and size-specific variation in mortality estimates of red abalone, Haliotis rufescens, from mark-recapture data in California. Fish Res 83:341-350

Leighton DL (1972) Laboratory observations on the early growth of the abalone, Haliotis sorenseni, and the effect of temperature on larval development and settling success. Fish Bull 70:373-380

Leighton DL (1974) The influence of temperature on larval and juvenile growth in three species of southern California abalones. Fish Bull 72:1137-1145

Levitan DR (1991) Influence of body size and population density on fertilization success and reproductive output in a free-spawning invertebrate. Biol Bull (Woods Hole) 181:261-268

Levitan DR, Sewell MA (1998) Fertilization success in freespawning marine invertebrates: review of the evidence and fisheries implications. In: Jamieson GS, Campbell A (eds) Proceedings of the North Pacific Symposium on Invertebrate Stock Assessment and Management. Can Spec Publ Fish Aquat Sci 125, NRC Research Press, Ottawa, p 159-164

Li Y, Jiao Y (2015) Evaluation of stocking strategies for endangered white abalone using a hierarchical demographic model. Ecol Model 299:14-22 
Lipcius RN, Eggleston DB, Schreiber SJ, Seitz RD and others (2008) Importance of metapopulation connectivity to restocking and restoration of marine species. Rev Fish Sci 16:101-110

Lorenzen K, Steneck RS, Warner RR, Parma AM, Coleman FC, Leber KM (2010) The spatial dimensions of fisheries: putting it all in place. Bull Mar Sci 86:169-177

National Marine Fisheries Service (NMFS) (2008) Final white abalone recovery plan (Haliotis sorenseni). National Marine Fisheries Service, Long Beach, CA

Nezlin NP, Oram JJ, DiGiacomo PM, Gruber N (2004) Subseasonal to interannual variations of sea surface temperature, salinity, oxygen anomaly, and transmissivity in Santa Monica Bay, California from 1987 to 1997. Cont Shelf Res 24:1053-1082

Orensanz J, Armstrong J, Armstrong D, Hilborn R (1998) Crustacean resources are vulnerable to serial depletion-the multifaceted decline of crab and shrimp fisheries in the Greater Gulf of Alaska. Rev Fish Biol Fish 8: $117-176$

Quinn TJ, Deriso RB (1999) Quantitative fish dynamics. Oxford University Press, New York, NY

Rogers-Bennett L (2002) Estimating baseline abundances of abalone in California for restoration. California Department of Fish and Game, Santa Cruz, CA

Rogers-Bennett L, Leaf RT (2006) Elasticity analyses of sizebased red and white abalone matrix models: management and conservation. Ecol Appl 16:213-224

Rogers-Bennett L, Melvin AS (2007) Size differences in wild and farmed red abalone: developing enforcement tools to combat illegal commercialization. Calif Fish Game 93: 77-85

Rogers-Bennett L, Haaker PL, Karpov KA, Kushner DJ (2002) Using spatially explicit data to evaluate marine protected areas for abalone in southern California. Conserv Biol 16:1308-1317

Rogers-Bennett L, Dondanville RF, Moore JD, Vilchis LI (2010) Response of red abalone reproduction to warm water, starvation, and disease stressors: implications of ocean warming. J Shellfish Res 29:599-611

Rogers-Bennett L, Aquilino KM, Catton CA, Kawana SK and others (2016a) Implementing a restoration program for the endangered white abalone (Haliotis sorenseni) in California. J Shellfish Res 35:611-618

Rogers-Bennett L, Dondanville RF, Catton CA, Juhasz CI, Horii T, Hamaguchi M (2016b) Tracking larval, newly settled, and juvenile red abalone (Haliotis rufescens) recruitment in northern California. J Shellfish Res 35: 601-610

Secor DH, Kerr LA, Cadrin SX (2009) Connectivity effects on productivity, stability, and persistence in a herring metapopulation model. ICES J Mar Sci 66: 1726-1732

Editorial responsibility: Steven Cooke, Ottawa, Ontario, Canada
Shepherd SA (1973) Studies on southern Australian abalone (Genus Haliotis) I: ecology of five sympatric species. Aust J Mar Freshw Res 24:217-257

Shepherd SA, Daume S (1996) Ecology and survival of juvenile abalone in a crustose coralline habitat in South Australia. In: Watanabe Y, Yamashita Y, Oozeki Y (eds) Survival strategies in early life stages of marine resources: International Workshop, Yokohama, Japan. A.A. Balkema, Rotterdam, p 297-313

Stierhoff KL, Neuman M, Butler JL (2012) On the road to extinction? Population declines of the endangered white abalone, Haliotis sorenseni. Biol Conserv 152:46-52

Straus KM, Friedman CS (2009) Restoration aquaculture of the pinto abalone (Haliotis kamtschatkana kamtschatkana Jonas): impacts of rearing method on behaviour, growth and survivorship in the hatchery. Mar Freshw Res 60:1021-1028

* Swartzman G, Huang C, Kaluzny S (1992) Spatial analysis of Bering Sea groundfish survey data using generalized additive models. Can J Fish Aquat Sci 49:1366-1378

Tang M (2012) Bayesian population dynamics modeling to guide population restoration and recovery of endangered mussels in the Clinch River, Tennessee and Virginia. MSc thesis, Virginia Tech University, Blacksburg, VA

Tarr RJ (2000) The South African abalone (Haliotis midae) fishery: a decade of challenges and change. In: Campbell A (ed) Workshop on Rebuilding Abalone Stocks in British Columbia. Can Spec Publ Fish Aquat Sci, 130, NRC Research Press, Ottawa, p 32-40

Tegner MJ (1989) The California abalone fishery: production, ecological interactions, and prospects for the future. In: Caddy JF (ed) Marine invertebrate fisheries: their assessment and management. John Wiley \& Sons, New York, NY, p 401-420

Tegner MJ, Butler RA (1985) The survival and mortality of seeded and native red abalones, Haliotis rufescens, on the Palos Verdes Peninsula (California, USA). Calif Fish Game 71:160-163

Tutschulte TC (1976) The comparative ecology of three sympatric abalones. PhD dissertation, University of California at San Diego, San Diego, CA

Vetter E (1988) Estimation of natural mortality in fish stocks: a review. Fish Bull 86:25-43

*Wiens JA, Stenseth NC, Van Horne B, Ims RA (1993) Ecological mechanisms and landscape ecology. Oikos 66: 369-380

* Winant CD, Bratkovich AW (1981) Temperature and currents on the southern California shelf: a description of the variability. J Phys Oceanogr 11:71-86

*Ying Y, Chen Y, Lin L, Gao T, Quinn T (2011) Risks of ignoring fish population spatial structure in fisheries management. Can J Fish Aquat Sci 68:2101-2120

Submitted: March 11, 2016; Accepted: December 16, 2016 Proofs received from author(s): March 7, 2017 